\title{
Stator Flux-Regulatory Excitation Control in Converter-Fed Synchronous Machines for Pumped-Storage Variable-Speed Hydropower
}

This paper was downloaded from TechRxiv (https://www.techrxiv.org).

\section{LICENSE}

CC BY 4.0

SUBMISSION DATE / POSTED DATE

$05-10-2021 / 12-10-2021$

\section{CITATION}

Stavnesli, Jørgen Hagset; Nøland, Jonas Kristiansen (2021): Stator Flux-Regulatory Excitation Control in Converter-Fed Synchronous Machines for Pumped-Storage Variable-Speed Hydropower. TechRxiv. Preprint. https://doi.org/10.36227/techrxiv.16746310.v1

$\mathrm{DOI}$ 


\title{
Stator Flux-Regulatory Excitation Control in Converter-Fed Synchronous Machines for Pumped-Storage Variable-Speed Hydropower
}

\author{
Jørgen Hagset Stavnesli and Jonas Kristiansen Nøland, Member, IEEE
}

\begin{abstract}
Pumped-storage hydropower is seen as a promising solution for efficient, large-scale energy storage. One competitive technical solution is the variable-speed hydropower plant (VSHP) configured with a converter-fed synchronous machine (CFSM). These machines are operated with one extra degree of freedom that is not usually optimized, where the CFSM's rotor-side DC excitation interacts with the stator-side AC excitation. Depending on machine loading, the CFSM will be utilized in conditions far from its original design. In order to deal with this issue, this paper presents a stator flux control (SFC) method for regulating VSHPs in a more efficient way by adjusting the field current to prevent the machine from operating with over-magnetization independent of loading condition, as well as better utilizing the stator-fed converter current, maximizing the utilization of the CFSM. The derived first-principle analytical equations for the proposed SFC have been validated and analyzed in the Matlab/Simulink environment for a large $45 \mathrm{MVA}, 375 \mathrm{rpm}$ CFSM, with the measured saturation curve as input. Finally, dynamic transitions between different levels of pumping power reveal the SFC's ability to help to maintain a unity stator flux in the machine, enabling optimal operation independent of loading level.
\end{abstract}

Index Terms-Excitation systems (ESs), flux regulation, wound-field synchronous machines (WFSMs), converter-fed synchronous machines (CFSMs), saturation modeling.

\section{INTRODUCTION}

$\mathbf{T}$ HE world is currently facing a transitioning face toward a larger share of renewable technologies [1]-[3]. In this energy transition era, the flexibility of the hydropower plant will be exploited to higher levels than ever before due to the intermittent nature of other renewable resources [3]. One solution to deal with this problem is to incorporate hydropower stations with a converter-fed motor-generator topology, which enables pumped storage variable-speed operation (PSVSO) [4]. This option is viewed as one of the most efficient largescale energy storage solutions currently known. It can even be utilized by grid-consumers far away from the power plant [5]. Such a system also has grid-supporting capabilities [6], and can help to deal with the future power system's challenges [7].

The machine solutions proposed for variable-speed hydropower plants (VSHPs) are converter-fed synchronous machines (CFSMs) [4], [8] and doubly-fed induction machines (DFIMs) [9]-[14], respectively. The CFSM is usually interfaced with a back-to-back (B2B) full-rated converter, which connects the VSHP to the power grid [15]. The common

J. H. Stavnesli is with ABB, e-mail: (jorghags@gmail.com).

J. K. Nøland is with the Norwegian University of Science and Technology (NTNU), Trondheim, Norway (e-mail: jonas.k.noland@ntnu.no).

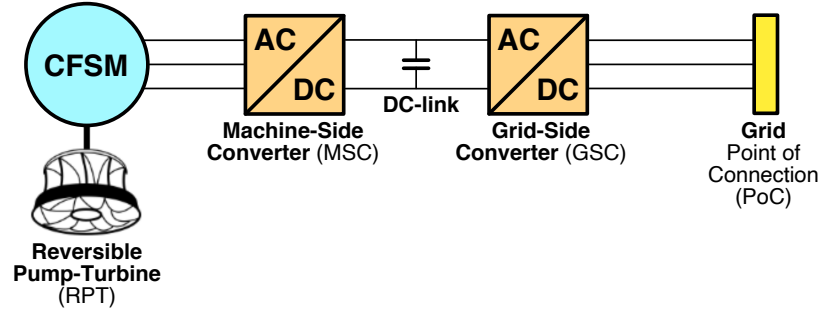

Fig. 1. Illustration of a converter-fed synchronous machine (CFSM) configuration for variable-speed hydropower plants (VSHPs) with a reversible pump-turbine. This topology is under investigation herein.

topologies are the two-level converter (2LC) [16], [17] and the three-level neutral point-clamped converter (3L-NPC) [18][20]. However, there are several flexibility and fault-tolerance benefits with the multilevel converter [21], [22]. Fig. 1 depicts the general topology for the CFSM-based VSHP, which is the investigated configuration in this paper.

The recent literature has proposed different functionalities for the control system of the VSHP [23], including maximum power point tracking (MPPT) of energy efficiency [24], model predictive control (MPC) [25], active disturbance rejection control (ADRC) [26]. Moreover, due to the inherent complexity of the VSHP, grid-interfacing and governor models have been proposed, where the CFSM has been approximated as a sixth-order [27] and second-order model [28], respectively. Also, improved hydro-turbine controls have been proposed for the PSVSO [29].

This paper deals with the detailed-level modeling of the CFSMs, and their interaction with the excitation system (ES) and the machine-side converter (MSC). The decoupling of the stator and the external grid means that the ES of the CFSM can be used for another purpose other than conventional AVR actions. Therefore, in this work, the role of the ES is analyzed with a focus on how the ES can be utilized to improve the operation of the CFSM. Separately excited synchronous machine drives are often controlled to operate with a unity power factor $(\cos \varphi=1)$, where the current and voltage terminal waveforms are in phase. A disadvantage of installing full-sized frequency converters in large hydropower plants is the associated converter losses. It is, therefore, of importance to reduce the converter losses by keeping the stator current low, when the converter is not bypassed. One possibility is to reduce this current by taking advantage of the ES's field current control to achieve the same electrical torque as with 
rated stator currents. However, a too high field current will saturate the machine, which is an undesirable way of operating the synchronous machine. In order to reduce the stator current while preventing the saturation of the machine, an excitation system (ES) with a stator flux controller (SFC) is proposed in this paper with the objective of maintaining a unitary stator flux magnitude (i.e., $\Psi_{s} \approx 1.0 \mathrm{pu}$ ). This is needed to make the CFSM able to operate with optimal excitation independent of loading level. The primary focus in this paper is put on analyzing the performance of the SFC and comparing it against alternatives which are the power factor control (PFC) of the excitation system (ES) with different field current regulation (FCR) levels.

The present paper is organized with the following structure. Section II provides details regarding the handpicked case study and the obtained data from the investigated hydropower plant. Then, a proposed stator flux estimation method is presented in Section III, comparing the performance with and without saturation taken into account. Finally, Section IV presents the main results of the stationary and dynamic performance of the proposed SFC with comparison to conventional approaches, before Section $\mathrm{V}$ concludes the paper.

\section{CASE Description And ObTained Data}

A complete schematic diagram of the CFSM topology in Fig. 1 is illustrated in Fig. 3 for pumping mode with its controllers and variables. In this mode of operation, the machineside converter (MSC) regulates the speed of the machine, and thus, the output power of the reversible pump-turbine. The speed control philosophy relies on aligning the stator current with the q-axis while the d-axis current is regulated to zero $\left(i_{d}=0\right)$ due to the low contribution from the reluctance torque of the given machine's saliency. In this paper, we propose that the excitation system (ES) will regulate the field current to maintain a $1.0 \mathrm{pu}$ stator flux linkage $\left(\Psi_{s}\right)$. This is achieved with the SFC strategy illustrated in Fig. 4.

The studied system was modeled in Matlab/Simulink environment using the Simscape Electrical library. The salientpole wound-field synchronous machine is rated with $45 \mathrm{MVA}$, and its key ratings can be found in Table I. Moreover, the machine characteristics were found using classical identification techniques [30], and the standard parameters are reported in Table II. Another important input for modeling is the noload saturation curve of the machine, which is provided from on-site measurements in Fig. 2. Our saturation curve model is expressed to match the experimentally obtained operating points, which is further explained in Section III. The machine case was handpicked based on similar real-world examples of CFSM systems, e.g., the 100 MVA Grimsel 2 power plant in Switzerland [31]. It is worth noting that small-scale machines have d-axis time constants more than one order of magnitude smaller than the larger ones, where the flux regulation becomes an easier task. The objective of the paper is to show that the SFC is feasible for MVA-sized machines and that analytical predictions can validate the simulations.

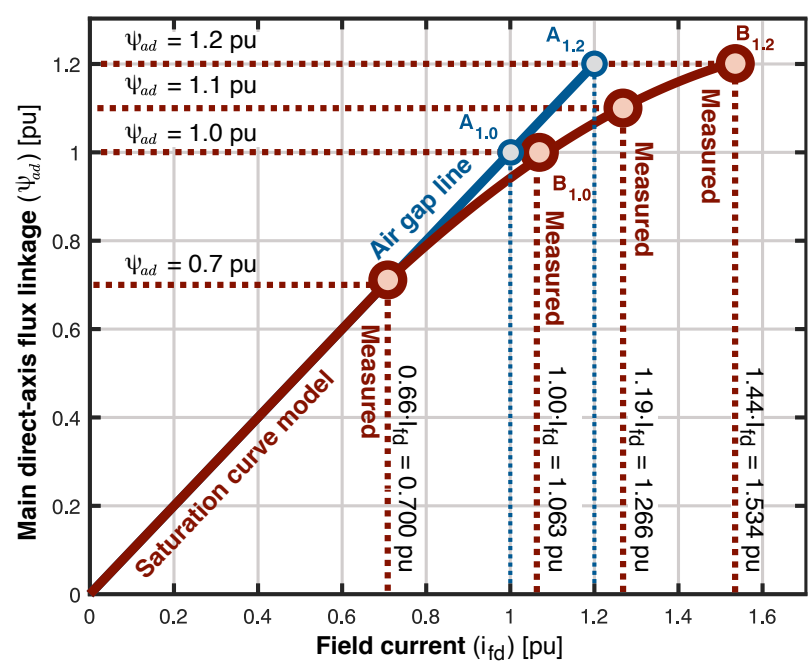

Fig. 2. The per-unit saturation curve of the $45 \mathrm{MVA}$ synchronous machine aligned with measured operating points at no-load conditions and rated speed $375 \mathrm{rpm}$.

TABLE I

CFSM MAChine Ratings in Generator Mode

\begin{tabular}{clc}
\hline \hline Symbol & Description & Value \\
\hline$S$ & Apparent power & $45.0 \mathrm{MVA}$ \\
$P$ & Active power & $42.0 \mathrm{MW}$ \\
$\cos (\varphi)$ & Rated power factor & 0.933 \\
$Q_{\max }$ & Maximum reactive power & $16.2 \mathrm{MVAr}$ \\
$Q_{\min }$ & Minimum reactive power & $-14.1 \mathrm{MVAr}$ \\
$U$ & Nominal voltage & $10 \mathrm{kV}$ \\
$I$ & Nominal current & $3674 \mathrm{~A}$ \\
$f$ & Nominal frequency & $50 \mathrm{~Hz}$ \\
$\mathrm{p}$ & Number of poles & 8 \\
$n$ & Nominal speed & $375 \mathrm{rpm}$ \\
$\mathrm{H}$ & Inertia time constant & $2.6 \mathrm{~s}$ \\
\hline \hline
\end{tabular}

TABLE II

ObTAINED STANDARd PARAMETERS OF THE CFSM

\begin{tabular}{clc}
\hline \hline Symbol & Description & Value \\
\hline$r_{s}$ & stator resistance $\left(20^{\circ} \mathrm{C} / 80^{\circ} \mathrm{C}\right)$ & $0.0024 \mathrm{pu} / 0.0030 \mathrm{pu}$ \\
$x_{l}$ & leakage react. & $0.1700 \mathrm{pu}$ \\
$x_{0}$ & zero sequence react. & $0.0810 \mathrm{pu}$ \\
$x_{2}$ & negative sequence react. & $0.1870 \mathrm{pu}$ \\
$x_{a d u}, x_{a d}^{*}$ & Main d-axis react. (unsat./sat.) & $0.7989 \mathrm{pu} / 0.7890 \mathrm{pu}$ \\
$x_{d}$ & d-axis react. (unsat./sat.) & $0.9689 \mathrm{pu} / 0.9590 \mathrm{pu}$ \\
$x_{d}^{\prime}$ & d-axis trans. react. (unsat./sat.) & $0.3428 \mathrm{pu} / 0.2990 \mathrm{pu}$ \\
$x_{d}^{\prime \prime}$ & d-axis sub-trans. react. (unsat./sat.) & $0.2279 \mathrm{pu} / 0.1980 \mathrm{pu}$ \\
$x_{q}^{\prime}$ & q-axis react. & $0.6870 \mathrm{pu}$ \\
$x_{q}^{\prime \prime}$ & q-axis sub-trans. react. & $0.2430 \mathrm{pu}$ \\
$T_{d o}^{\prime}$ & d-axis OC trans. time (sat./unsat.) & $5.9170 \mathrm{~s} / 5.5680 \mathrm{~s}$ \\
$T_{d}^{\prime}$ & d-axis SC trans. time (sat./unsat.) & $1.3380 \mathrm{~s} / 1.1630 \mathrm{~s}$ \\
$T_{d}^{\prime \prime}$ & d-axis SC sub-trans. time (sat./unsat.) & $0.0280 \mathrm{~s} / 0.0250 \mathrm{~s}$ \\
$T_{q}^{\prime \prime}$ & q-axis SC sub-trans. time & $0.0380 \mathrm{~s}$ \\
\hline \hline
\end{tabular}

\section{Stationary ANALysis of THE CFSM}

This section formulates the proposed approach for stator flux estimation of the CFSM based on currents and voltages at the machine-side converter (MSC). The estimation is used to obtain the needed field current reference $\left(i_{f d}^{r e f}\right)$ for the excitation system (ES). In the dq-equivalent circuit frame, the stator flux $\left(\Psi_{s}\right)$ can be found as a projection of the d- and q- 
TABLE III

CONTROL PARAMETERS USED IN THIS PAPER

\begin{tabular}{|c|c|c|c|c|c|}
\hline Parameter & $\begin{array}{l}\text { Power factor } \\
\text { controller }\end{array}$ & $\begin{array}{l}\text { Outer-loop } \\
\text { speed controller }\end{array}$ & $\begin{array}{l}\text { Field current } \\
\text { controller }\end{array}$ & $\begin{array}{l}\text { Quadrature current } \\
\text { controller }\end{array}$ & $\begin{array}{l}\text { Direct current } \\
\text { controller }\end{array}$ \\
\hline Proportional gain $\left(K_{p}\right)$ & $i_{d, r e f}=i_{q}\left(u_{d} / u_{q}\right)$ & $1.584 \mathrm{pu} / \mathrm{pu}$ & $1.4854 \mathrm{pu} / \mathrm{pu}$ & $1.4064 \mathrm{pu} / \mathrm{pu}$ & $1.1459 \mathrm{pu} / \mathrm{pu}$ \\
\hline Integral gain $\left(K_{i}\right)$ & $\mathrm{n} / \mathrm{a}$ & $71.3 \mathrm{pu} / \mathrm{pu} \cdot \mathrm{s}$ & $29.4631 \mathrm{pu} / \mathrm{pu} \cdot \mathrm{s}$ & $5.7199 \mathrm{pu} / \mathrm{pu} \cdot \mathrm{s}$ & $4.8301 \mathrm{pu} / \mathrm{pu} \cdot \mathrm{s}$ \\
\hline Output saturation & $\mathrm{n} / \mathrm{a}$ & $\omega_{m e c h}= \pm 1.0 \mathrm{pu}$ & $u_{f d}= \pm 2.0 \mathrm{pu}$ & $i_{q}= \pm 1.0 \mathrm{pu}$ & $i_{d}= \pm 0.4 \mathrm{pu}$ \\
\hline
\end{tabular}

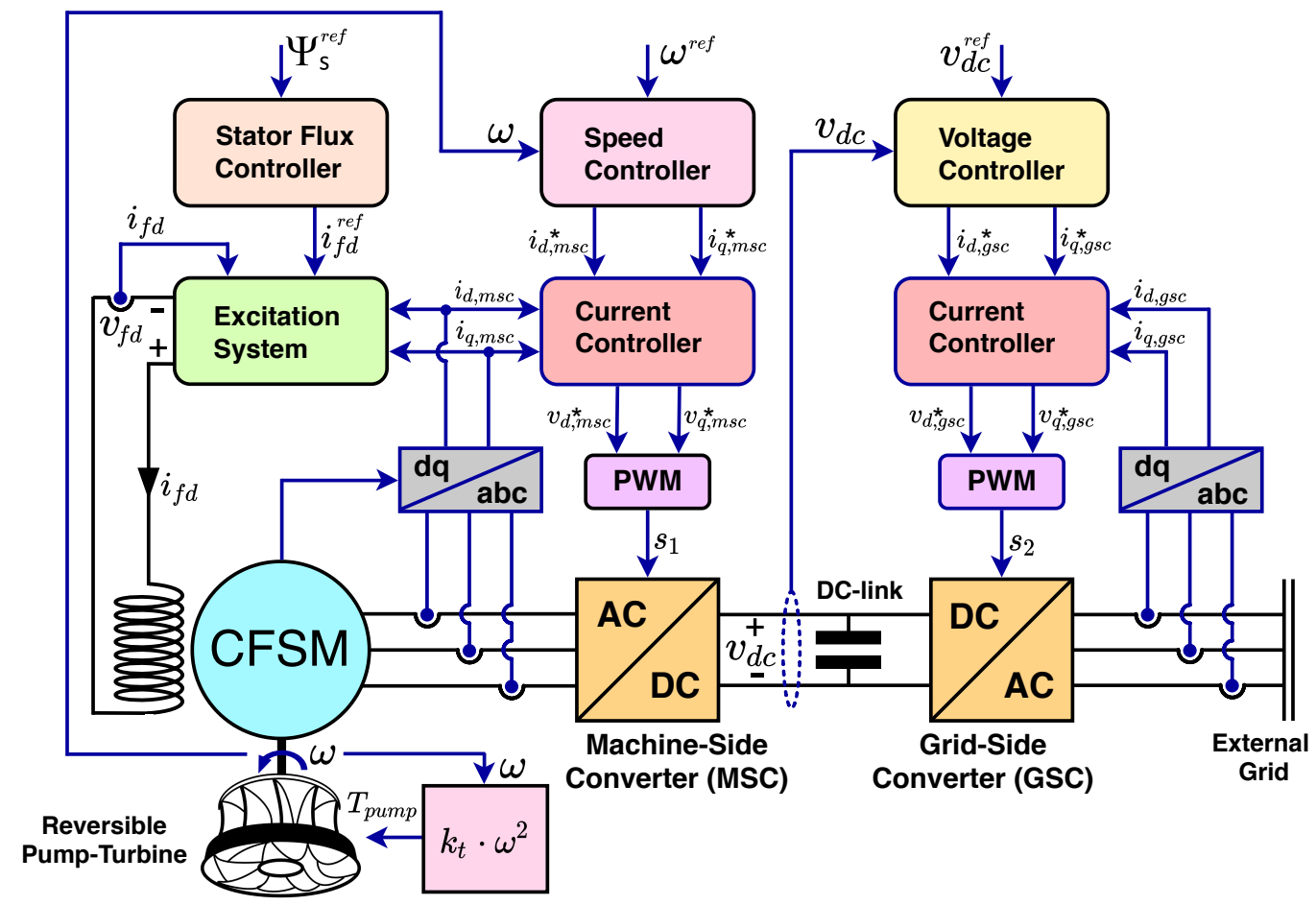

Fig. 3. Overview of the variable speed hydropower CFSM in pump mode and its controllers. Stator flux controller (SFC) is further described in Fig. 4.

axis flux linkages $\left(\psi_{d}\right.$ and $\left.\psi_{q}\right)$ in eq. (1) as follows.

$$
\Psi_{s}=\sqrt{\psi_{d}^{2}+\psi_{q}^{2}}
$$

The equivalent circuit's dq-axis flux linkages, can be expressed further as,

$$
\begin{gathered}
\psi_{d}=x_{a d} i_{f d}+x_{d} i_{d}=\underbrace{x_{a d}\left(i_{f d}+i_{d}\right)}_{\psi_{a d}}+x_{l} i_{d}, \\
\psi_{q}=x_{q} i_{q}=\left(x_{a q}+x_{l}\right) i_{q} .
\end{gathered}
$$

In system studies of salient pole synchronous machines, a common assumption is that the q-axis mutual reactance does not saturate, mainly because the q-axis flux is usually quite small in comparison to the d-axis flux (large air gap height in the q-axis). Therefore, $x_{a q}$ is assumed to be constant, independent of the magnetization of the machine such that $x_{q}$ can be used as a constant parameter in the next equations.

By inserting eqs. (2) and (3) into eq. (1), one obtains

$$
\Psi_{s}=\sqrt{\left(x_{a d} i_{f d}+\left(x_{a d}+x_{l}\right) i_{d}\right)^{2}+\left(x_{q} i_{q}\right)^{2}} .
$$

An equation for the optimal field current can then be obtained, yielding

$$
i_{f d}=\frac{1}{x_{a d}} \sqrt{\Psi_{s}^{2}-\left(x_{q} i_{q}\right)^{2}}-\left(1+\frac{x_{l}}{x_{a d}}\right) i_{d},
$$

which is plotted for variations of $i_{d}$ and $i_{q}$ in Fig. 5 .

\section{A. Stator Flux Controller (SFC)}

By setting both $\Psi_{s}=1 \mathrm{pu}$ and $i_{d}=0$, eq. (5) can be modified to obtain the field current reference $i_{f d}^{r e f}$, yielding

$$
i_{f d}^{r e f}=\frac{1}{x_{a d}} \sqrt{1-\left(x_{q} i_{q}\right)^{2}}
$$

The field current $\left(i_{f d}\right)$ should be regulated according to eq. (5), to keep the stator flux linkage $\left(\Psi_{s}\right)$ constant at $1.0 \mathrm{pu}$. This strategy is graphically illustrated in Fig. 4, where a saturation model for parameter $x_{a d}$ is incorporated, which will be further described below. The different variables comprising eq. (5) are as follows.

1) Two parameters are assumed to be constant, i.e., the quadrature axis reactance $\left(x_{q}\right)$ and the stator leakage reactance $\left(x_{l}\right)$. 


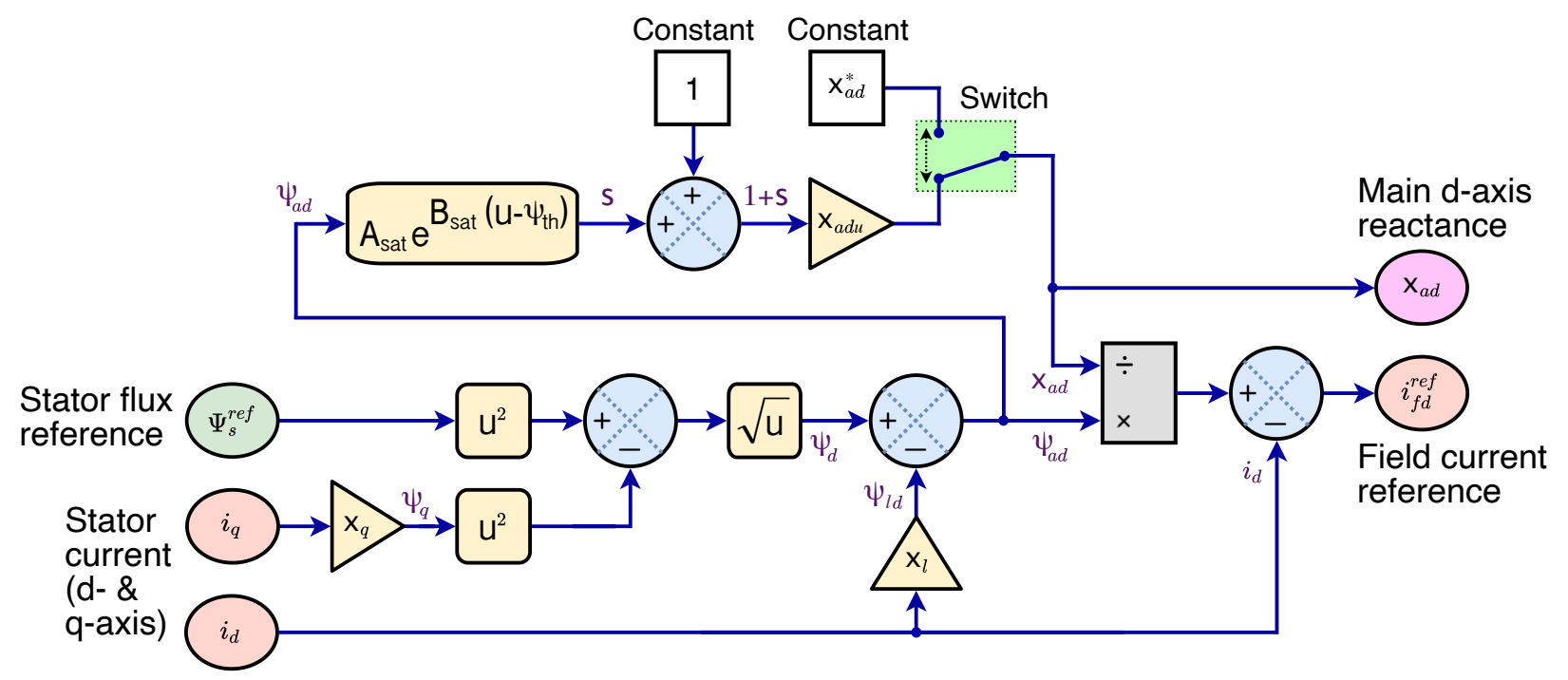

Fig. 4. Overview of the proposed SFC based on eqs. (5) and (12) with $i_{d}$ and $i_{q}$ as input variables from the MSC and a saturation model for $x_{a d}$.

(a)

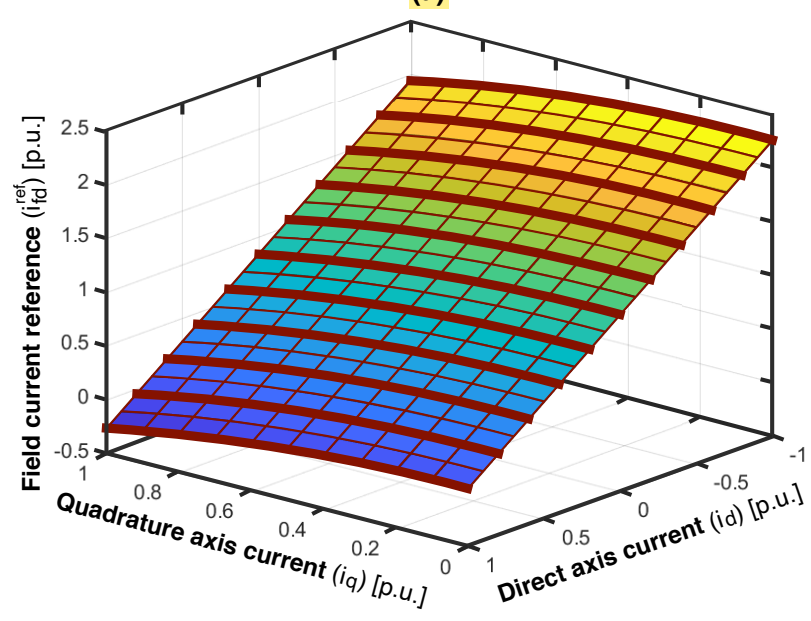

(b)

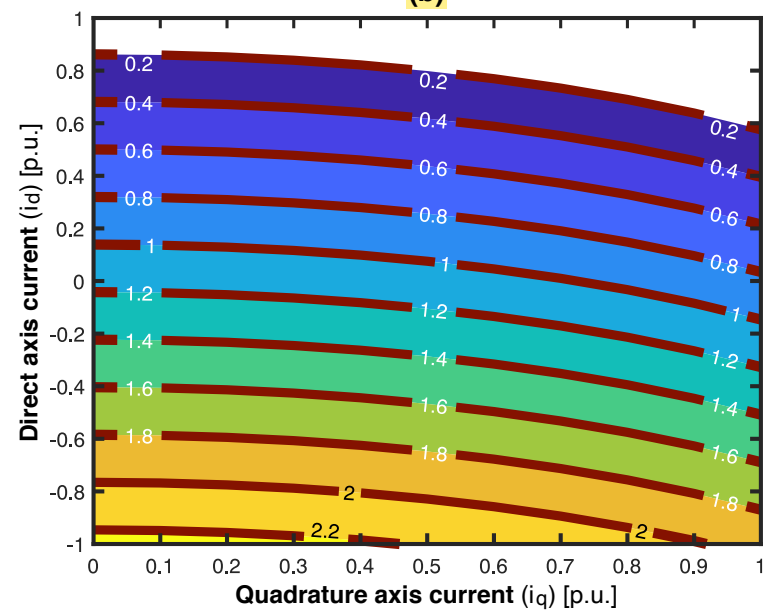

Fig. 5. Plot of the non-saturated field current reference $i_{f d}^{r e f}$ from eq. (5) for a $1 \mathrm{pu}$ stator flux $\left(\Psi_{s}\right)$ as a function of d- and q-axis currents $\left(i_{d}\right.$ and $\left.i_{q}\right)$. The 45 MVA converter-fed synchronous machine (CFSM) is considered. a): Surface plot. b): Contour plot.
2) One parameter, the main direct axis reactance $\left(x_{a d}\right)$ is assumed to be a constant up to a certain magnetization level, but depends strongly on the field current $\left(i_{f d}\right)$. A saturation curve predicts $x_{a d}=f\left(\psi_{a d}\right)$, depending on the saturation of the machine.

In order to simplify the strategy, the saturation of the machine can be neglected, which is illustrated in Fig. 4 as a binary switch, assuming a constant main direct axis reactance $\left(x_{a d}^{*}\right)$. However, this approach will only be effective if the machine is operated in a highly under-excited mode, limiting the CFSM's power levels. The dq-axis currents are regulated by the machine-side converter (MSC), and the excitation system (ES) sets the stator flux linkage reference to $1.0 \mathrm{pu}$. The MSC sets the d-axis current reference to zero to maximize the torque generation of the CFSM without reluctance torque. This condition implies that the MSC cannot be operated at unity power factor control in the SFC regime. Such control would interact with d-axis current $\left(i_{d}\right)$ that fights against the flux regulation of the proposed $\mathrm{ES}$. As a comparative reference to the proposed SFC, a unity power factor controller (PFC) can be analyzed with the ES operated as a field current regulator (FCR). All controller parameters considered to study the proposed SFC against the alternative PFC in the case studies presented in Section IV are given in Table III.

\section{B. Saturation Modeling}

A further improvement of the SFC is to include saturation of the d-axis main reactance $\left(x_{a d}\right)$. This aspect could be neglected, but the effect must be included for achieving an accurate stator flux estimation. The modeling of the d-axis main reactance $\left(x_{a d}\right)$ could be made based on a saturation curve depicted in Fig. 2, expressing $x_{a d}$ as a function of the CFSM stator's main direct axis flux linkage $\left(\psi_{a d}\right)$. This is done in the region where the true saturation curve diverges from the air-gap line, which occurs for flux levels above $0.7 \mathrm{pu}\left(\psi_{t h}\right)$. Based on the data points $A_{1.0}, A_{1.2}, B_{1.0}$ and $B_{1.2}$ in Fig. 2, 
TABLE IV

SATURATION DATA OBTAINED FROM FIG. 2

\begin{tabular}{lccccccccc}
\hline \hline Parameter & $\mathbf{A}_{\mathbf{1 . 0}}$ & $\mathbf{A}_{\mathbf{1 . 2}}$ & $\mathbf{B}_{\mathbf{1 . 0}}$ & $\mathbf{B}_{\mathbf{1 . 2}}$ & $\mathbf{s} \mathbf{1 0}$ & $\mathbf{s}_{\mathbf{1 2}}$ & $\mathbf{A}_{\mathbf{s a t}}$ & $\mathbf{B}_{\mathbf{s a t}}$ & $\psi_{\text {th }}$ \\
\hline Value & $1.000 \mathrm{pu}$ & $1.200 \mathrm{pu}$ & $1.063 \mathrm{pu}$ & $1.534 \mathrm{pu}$ & $0.063 \mathrm{pu}$ & $0.278 \mathrm{pu}$ & $0.012 \mathrm{pu}$ & $1.933 \mathrm{pu}$ & $0.7 \mathrm{pu}$ \\
\hline \hline
\end{tabular}

TABLE V

AnAlytical Validation of Operating Points inVestigated in Figure 6, WHERE D-AXIS FLUX IS $\psi_{d}=x_{a d} i_{f d}, i_{d}=0, \psi_{d}=\psi_{a d}$, Q-AXIS FLUX IS $\psi_{q}=x_{q} i_{q}$, AND THE TOTAL FLUX LINKAGE IS $\Psi_{s}=1$.

\begin{tabular}{|c|c|c|c|c|c|c|c|c|c|c|c|}
\hline $\mathbf{P}_{\text {pump }}$ & $\omega_{\text {mech }}$ & $\mathbf{i}_{\mathrm{d}}$ & $\mathbf{i}_{\mathbf{q}}$ & $\psi_{\mathrm{d}}$ & $\psi_{\mathrm{g}}$ & $\mathbf{x}_{\mathbf{a d u}}$ & $\mathbf{i}_{\text {fdu }}$ & $\mathbf{s}$ & $\mathbf{x}_{\mathrm{ad}}$ & $\mathbf{i}_{\mathrm{fd}}$ & $\mathbf{i}_{\mathbf{f d}} \operatorname{sim}$ \\
\hline $0.0000 \mathrm{pu}$ & $0.0000 \mathrm{pu}$ & $0.0 \mathrm{pu}$ & $0.0 \mathrm{pu}$ & $1.0000 \mathrm{pu}$ & $0.0000 \mathrm{pu}$ & $0.7989 \mathrm{pu}$ & $1.2517 \mathrm{pu}$ & 0.0214 & $0.7821 \mathrm{pu}$ & $1.2785 \mathrm{pu}$ & $1.278 \mathrm{pu}$ \\
\hline $0.0688 \mathrm{pu}$ & $0.4097 \mathrm{pu}$ & $0.0 \mathrm{pu}$ & $0.1 \mathrm{pu}$ & $0.9976 \mathrm{pu}$ & $0.0687 \mathrm{pu}$ & $0.7989 \mathrm{pu}$ & $1.2488 \mathrm{pu}$ & 0.0213 & $0.7822 \mathrm{pu}$ & $1.2754 \mathrm{pu}$ & $1.275 \mathrm{pu}$ \\
\hline $0.1920 \mathrm{pu}$ & $0.5769 \mathrm{pu}$ & $0.0 \mathrm{pu}$ & $0.2 \mathrm{pu}$ & $0.9905 \mathrm{pu}$ & $0.1374 \mathrm{pu}$ & $0.7989 \mathrm{pu}$ & $1.2398 \mathrm{pu}$ & 0.0210 & $0.7824 \mathrm{pu}$ & $1.2659 \mathrm{pu}$ & $1.266 \mathrm{pu}$ \\
\hline $0.3454 \mathrm{pu}$ & $0.7016 \mathrm{pu}$ & $0.0 \mathrm{pu}$ & $0.3 \mathrm{pu}$ & $0.9785 \mathrm{pu}$ & $0.2061 \mathrm{pu}$ & $0.7989 \mathrm{pu}$ & $1.2248 \mathrm{pu}$ & 0.0206 & $0.7828 \mathrm{pu}$ & $1.2500 \mathrm{pu}$ & $1.250 \mathrm{pu}$ \\
\hline $0.5164 \mathrm{pu}$ & $0.8023 \mathrm{pu}$ & $0.0 \mathrm{pu}$ & $0.4 \mathrm{pu}$ & $0.9615 \mathrm{pu}$ & $0.2748 \mathrm{pu}$ & $0.7989 \mathrm{pu}$ & $1.2035 \mathrm{pu}$ & 0.0199 & $0.7833 \mathrm{pu}$ & $1.2275 \mathrm{pu}$ & $1.227 \mathrm{pu}$ \\
\hline $0.6934 \mathrm{pu}$ & $0.8851 \mathrm{pu}$ & $0.0 \mathrm{pu}$ & $0.5 \mathrm{pu}$ & $0.9392 \mathrm{pu}$ & $0.3435 \mathrm{pu}$ & $0.7989 \mathrm{pu}$ & $1.1756 \mathrm{pu}$ & 0.0191 & $0.7840 \mathrm{pu}$ & $1.1980 \mathrm{pu}$ & $1.198 \mathrm{pu}$ \\
\hline $0.8666 \mathrm{pu}$ & $0.9534 \mathrm{pu}$ & $0.0 \mathrm{pu}$ & $0.6 \mathrm{pu}$ & $0.9111 \mathrm{pu}$ & $0.4122 \mathrm{pu}$ & $0.7989 \mathrm{pu}$ & $1.1404 \mathrm{pu}$ & 0.0180 & $0.7847 \mathrm{pu}$ & $1.1610 \mathrm{pu}$ & $1.161 \mathrm{pu}$ \\
\hline $1.0272 \mathrm{pu}$ & $1.009 \mathrm{pu}$ & $0.0 \mathrm{pu}$ & $0.7 \mathrm{pu}$ & $0.8768 \mathrm{pu}$ & $0.4809 \mathrm{pu}$ & $0.7989 \mathrm{pu}$ & $1.0975 \mathrm{pu}$ & 0.0169 & $0.7856 \mathrm{pu}$ & $1.1160 \mathrm{pu}$ & $1.116 \mathrm{pu}$ \\
\hline $1.1576 \mathrm{pu}$ & $1.05 \mathrm{pu}$ & $0.0 \mathrm{pu}$ & $0.8 \mathrm{pu}$ & $0.8354 \mathrm{pu}$ & $0.5496 \mathrm{pu}$ & $0.7989 \mathrm{pu}$ & $1.0457 \mathrm{pu}$ & 0.0156 & $0.7866 \mathrm{pu}$ & $1.0620 \mathrm{pu}$ & $1.062 \mathrm{pu}$ \\
\hline $1.2527 \mathrm{pu}$ & $1.078 \mathrm{pu}$ & $0.0 \mathrm{pu}$ & $0.9 \mathrm{pu}$ & $0.7859 \mathrm{pu}$ & $0.6183 \mathrm{pu}$ & $0.7989 \mathrm{pu}$ & $0.9838 \mathrm{pu}$ & 0.0142 & $0.7877 \mathrm{pu}$ & $0.9977 \mathrm{pu}$ & $0.9978 \mathrm{pu}$ \\
\hline $1.2950 \mathrm{pu}$ & $1.09 \mathrm{pu}$ & $0.0 \mathrm{pu}$ & $1.0 \mathrm{pu}$ & $0.7267 \mathrm{pu}$ & $0.6870 \mathrm{pu}$ & $0.7989 \mathrm{pu}$ & $0.9096 \mathrm{pu}$ & 0.0126 & $0.7889 \mathrm{pu}$ & $0.9211 \mathrm{pu}$ & $0.9212 \mathrm{pu}$ \\
\hline
\end{tabular}

two saturation factors ( $s_{10}$ and $s_{12}$ ) can be found [32], which as given in Table IV. They can be expressed as follows.

$$
\begin{aligned}
& s_{10}=\frac{B_{1.0}-A_{1.0}}{A_{1.0}} \\
& s_{12}=\frac{B_{1.2}-A_{1.2}}{A_{1.2}}
\end{aligned}
$$

Then, two saturation constants $\left(A_{\text {sat }}\right.$ and $\left.B_{\text {sat }}\right)$ can be defined as follows [33].

$$
\begin{gathered}
A_{\text {sat }}=\frac{s_{10}^{2}}{1.2 \cdot s_{12}} \\
B_{\text {sat }}=5 \cdot \ln \left(1.2 \cdot \frac{s_{12}^{2}}{s_{10}}\right)
\end{gathered}
$$

As a result, based on the terminal stator flux linkage of the machines $\left(\Psi_{s}\right)$, a saturation factor $(s)$ can be calculated for all operating points, where

$$
s=A_{s a t} \cdot e^{B_{s a t} \cdot\left(\psi_{a d}-\psi_{t h}\right)}
$$

Eq. (11) has a threshold constant, $\psi_{t h}=0.7 \mathrm{pu}$, which is the point where the saturation curve diverges from the air-gap curve (as seen in Fig. 2). If the CFSM operates at nominal mechanical speed $(1 \mathrm{pu})$, the stator flux $\left(\Psi_{s}\right)$ and the terminal voltage $\left(U_{t}\right)$ are both equal to $1 \mathrm{pu}$.

Finally, $x_{a d}$ can be expressed as

$$
x_{a d}=\frac{x_{a d u}}{1+s}=\frac{x_{a d u}}{1+A_{s a t} \cdot e^{B_{s a t} \cdot\left(\psi_{a d}-\psi_{t h}\right)}},
$$

which is incorporated in the proposed SFC illustration in Fig. 4. As already mentioned, this method assumes that $x_{a d}$ is unsaturated (i.e., $x_{a d}=x_{a d u}$ ) until the stator flux linkage reaches $0.7 \mathrm{pu}\left(\psi_{t h}\right)$, i.e., $s=0$. Beyond this, the saturation factor $(s)$ is taken into account when calculating $x_{a d}$. The stationary characteristic of eq. (12) is plotted in Fig. 7a).

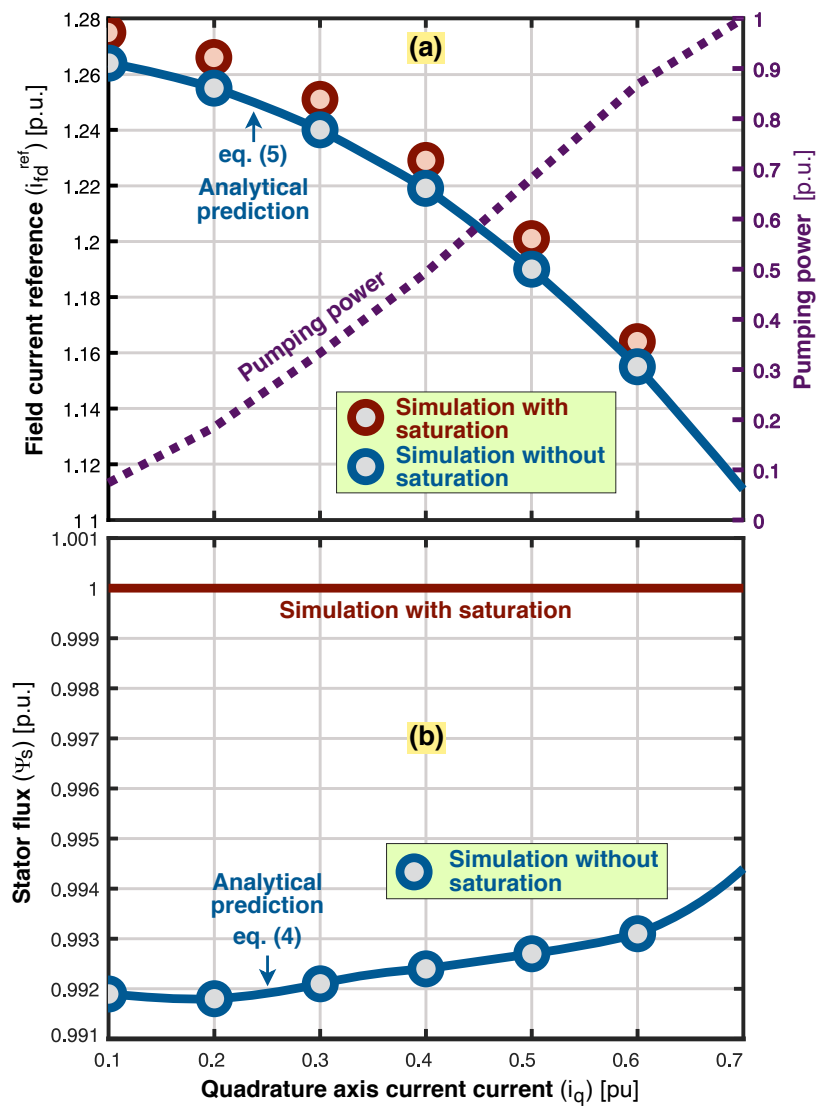

Fig. 6. Validation of the analytical eqs. (4) and (5) against the simulation model for different stationary operating points comparing the field current references producing $\Psi_{s}=1 \mathrm{pu}$ with and without saturation modeling by varying $i_{q}$ from $0.1 \mathrm{pu}$ to $0.7 \mathrm{pu}$, while keeping d-axis current at $0.0 \mathrm{pu}$. a): Field current reference $\left(i_{f d}^{r e f}\right)$. b): Stator flux $\left(\Psi_{S}\right)$

\section{Electric Load Modeling in Pumping Mode}

The pumping power is given by a classical cubic relationship with the mechanical speed in SI-units, yielding

$$
P_{\text {pump }}=k_{\text {pump }} \cdot \omega_{\text {mech }}^{3}, \quad T_{\text {pump }}=k_{\text {pump }} \cdot \omega_{\text {mech }}^{2},
$$


where $k_{\text {pump }}$ is defined by the base power $\left(S_{b}\right)$ of the CFSM and the base mechanical speed $\left(\omega_{b}\right)$

$$
k_{\text {pump }}=\frac{S_{b}}{\omega_{b}^{3}} .
$$

In per-unit notation, eq. (13) is reduced such that the perunit pumping power $\left(P_{\text {pump }}\right)$ and pumping torque $\left(T_{\text {pump }}\right)$ is proportional to the per-unit mechanical speed $\left(\omega_{\text {mech }}\right)$ cubed,

$$
P_{\text {pump }}=\omega_{\text {mech }}^{3}, \quad T_{\text {pump }}=\omega_{\text {mech }}^{2} .
$$

With $i_{d}=0$, the electrical torque is

$$
T_{\text {pump }}=\frac{3}{2} \cdot \psi_{d} \cdot i_{q}
$$

when $\psi_{d}$ and $i_{q}$ are amplitude-invariant values in per unit.

\section{MAin Results, VALIDATIONS AND COMPARISONS}

This section takes the stator flux estimation method of Section III onboard to analyze further its performances for the case study CFSM described in Section II. First, the proposed stator flux controller (SFC) is studied with and without taking saturation into account. Then, a benchmark is made with respect to the conventional unity power factor control (PFC) for the converter-fed machine system.

\section{A. Analytical Validation of SFC with \& without Saturation}

In order to examine how the machine is affected by neglecting saturation of the d-axis main reactance $\left(x_{a d}\right)$, a stationary validation of the analytical equations are presented in Fig. 6 and Table $\mathrm{V}$, where the predicted $i_{f d}^{r e f}$ to achieve unity stator flux agrees well with the simulation model (assessment against simulated $i_{d f}^{s i m}$ in last column). The transient performance was also investigated by performing a dynamic load step simulation. Here, the machine is simulated in steady-state with $0.06 \mathrm{pu}$ pumping power and then increased to $0.51 \mathrm{pu}$. The numerical results are shown in Fig. 7. These plots further indicate the importance of modeling the saturation. By assuming a constant $\mathrm{d}$-axis mutual reactance $\left(x_{a d}\right)$, the actual decrease of reactance caused by the increase in machine flux as the speed and voltage reach higher levels is not captured. This leads to a field current reference that is too low, thereby, creating stator magnitude less than $1.0 \mathrm{pu}$. Moreover, it shows that the inclusion of saturation provides a higher field current reference for the ES to keep the stator flux at $1.0 \mathrm{pu}$.

\section{B. Comparison of SFC Against PFC}

In this subsection, the SFC is compared to a unity power factor controller (PFC) with $\cos (\varphi)=1$ control for different set points of the field current. These are taken from Fig. 2 as follows.

1) A case where the nominal field current $\left(I_{f d}\right)$ is used as the reference for the ES (i.e., $i_{f d}=1.063 \mathrm{pu}$ ), which is the field current needed to achieve rated machine flux or rate open-circuit terminal voltage (1.0 pu).

2) An over-magnetized case where the field current is set to $1.19 I_{f d}$ (i.e., $i_{f d}=1.266 \mathrm{pu}$ ), yielding an open-circuit stator flux of $1.1 \mathrm{pu}$.
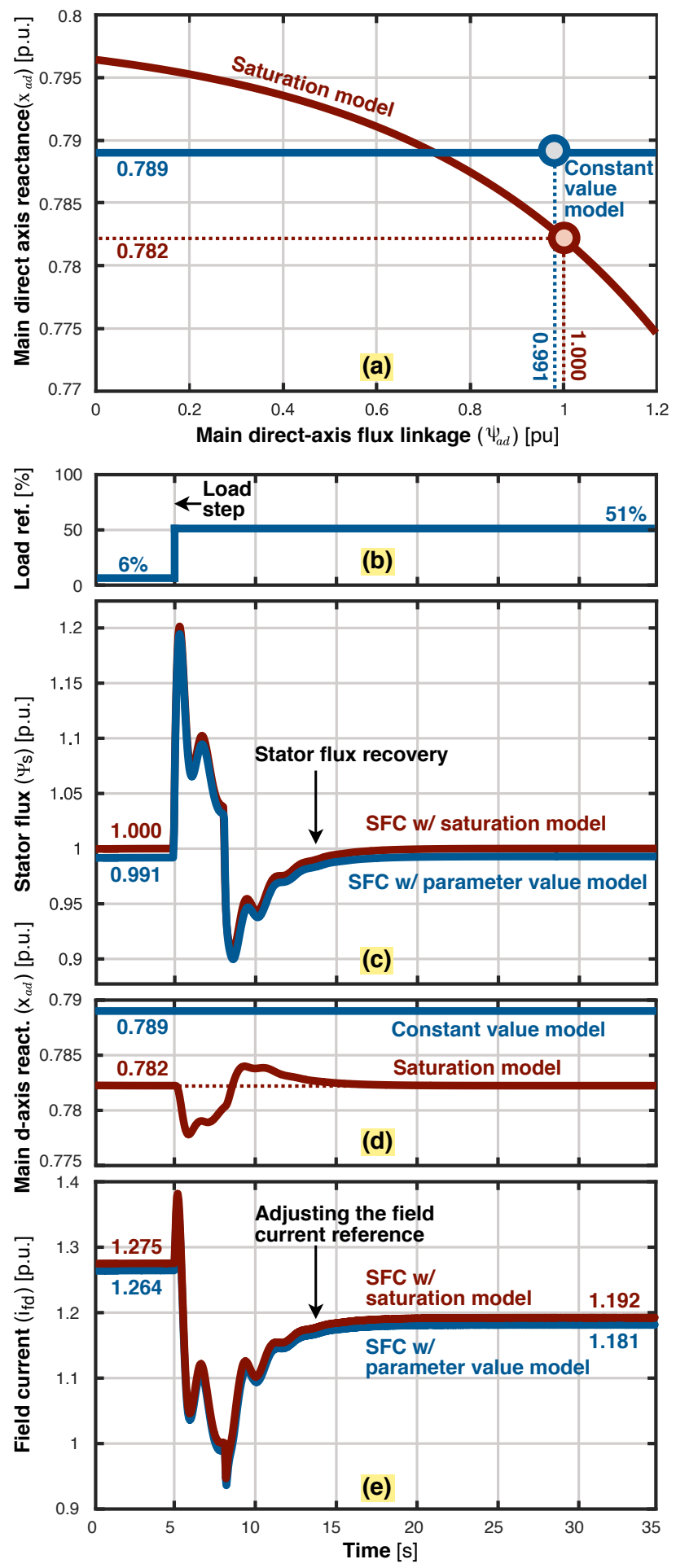

Fig. 7. Comparison between saturation model and constant parameter model. a): Main direct axis reactance $\left(x_{a d}\right)$ as a function of the stator main direct axis flux $\left(\psi_{a d}\right)$, used for stator flux control (SFC). It is based on eq. (12). b): Load reference step at time instant $5 \mathrm{~s}$ equivalent to ramping from $6 \%$ to $51 \%$ in pumping power, from initial speed $0.4 \mathrm{pu}$ and then increased to $0.8 \mathrm{pu}$, used for comparing stator flux control (SFC) with and without saturation modelling. c): Stator flux $\left(\Psi_{S}\right)$. d): Main d-axis reactance $\left(x_{a d}\right)$. e): Field current $\left(i_{f d}\right)$. 


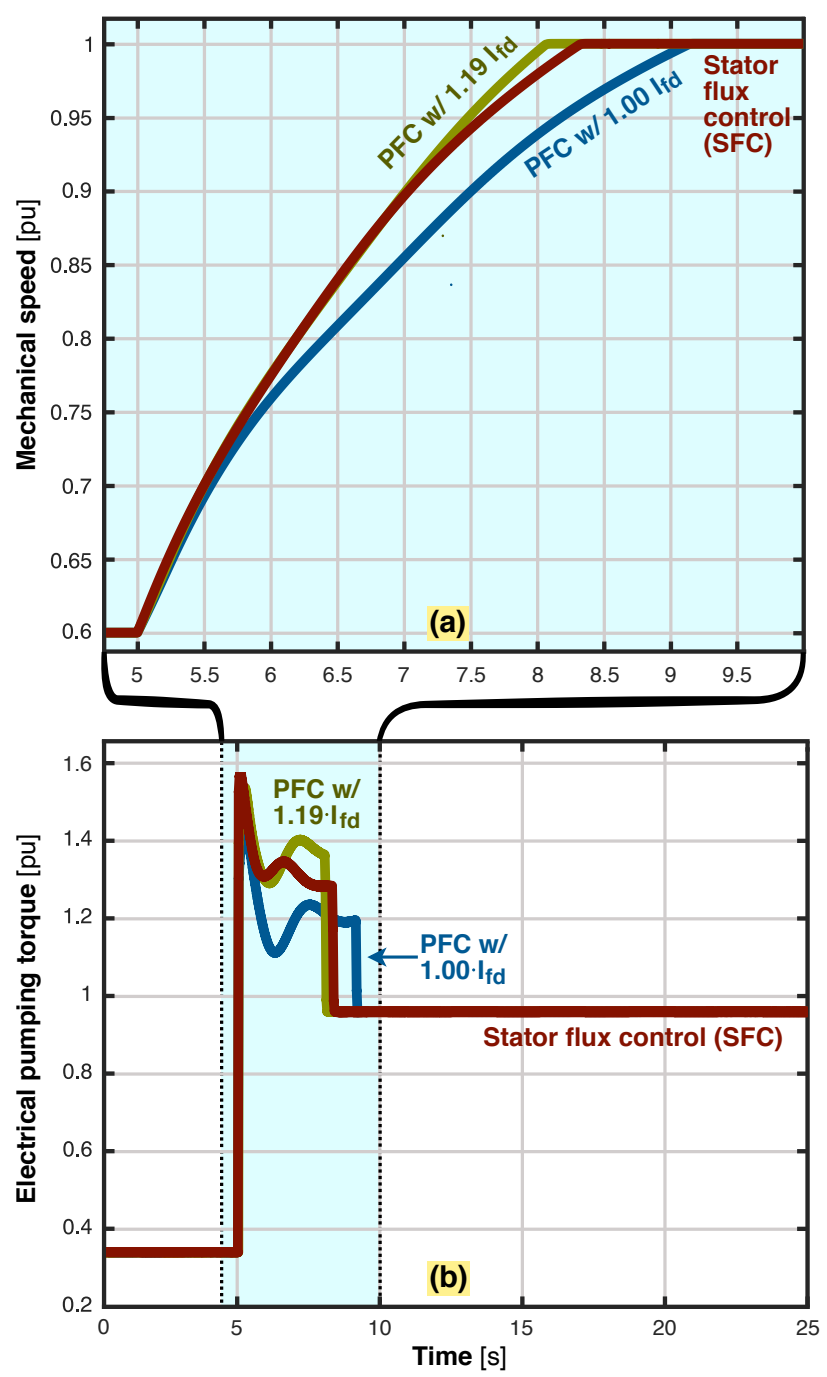

Fig. 8. Speed transition of the CFSM for the different control strategies when ramping pumping power from $20 \%$ to $100 \%$. $1.0 I_{f d}$ corresponds to $i_{f d}=1.063 \mathrm{pu}$. Similarly, $1.19 I_{f d}$ corresponds to $i_{f d}=1.266 \mathrm{pu}$. a): Mechanical speed. b): Electrical pumping torque.

The load step simulation considers a case where the reference speed of the machine is changed simultaneously from $0.6 \mathrm{pu}$ to $1.0 \mathrm{pu}$. This is equivalent to increasing the pump load from approximately $20 \%$ to $100 \%$ loading. The results are shown in Figs. 8, 9, 10, and 11. The load step analysis presents two ways of controlling a variable-speed electrically-excited synchronous machine as follows.

1) Optimal machine operation where the machine is kept out of over-magnetization.

2) Optimal converter operation where the power drawn from the converter is at unity power factor.

These two objectives cannot be achieved simultaneously, as the power factor control (PFC) adjusting the d-axis current $\left(i_{d}\right)$ comes into direct conflict with the stator flux regulator on the field current controller. This is because both field current and $\mathrm{d}$-axis current will affect the d-axis component of the stator flux vector.

In Fig. 8, the SFC is shown to achieve high transient torque, even though d-axis current can be kept to zero, implying no
TABLE VI

INITIAL AND FINAL STATOR FLUX $\left(\Psi_{s}\right)$ BEFORE AND AFTER THE SPEED TRANSITION IN FIGS. 8-11, COMPARING THE DIFFERENT METHODS

\begin{tabular}{lcc}
\hline \hline Method & Initial & Final \\
\hline Stator flux control (SFC) & $1.000 \mathrm{pu}$ & $1.000 \mathrm{pu}$ \\
PFC w/ $1.00 \cdot I_{f d}$ & $0.904 \mathrm{pu}$ & $1.309 \mathrm{pu}$ \\
PFC w/ $1.19 \cdot I_{f d}$ & $1.030 \mathrm{pu}$ & $1.330 \mathrm{pu}$ \\
\hline \hline
\end{tabular}
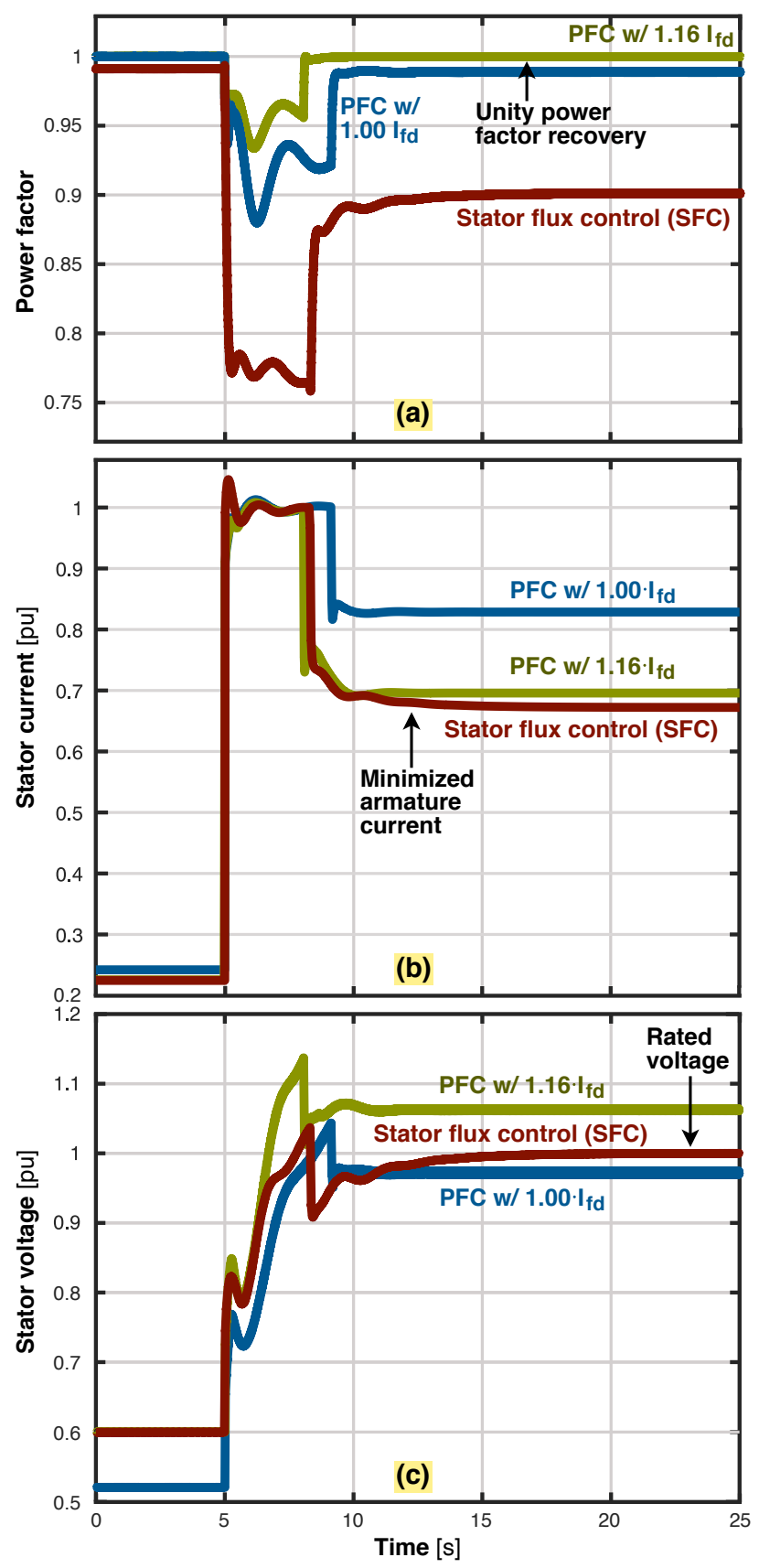

Fig. 9. The load step is the same as presented in Fig. 8. a): Power factor. b): Stator current. c): Stator voltage.

reluctance torque. This implies that the transition phase of the load step is comparable to the PFC. The main converter benefit of PFC is that the unity power factor is recovered after the load step. This is seen in Fig. 9. However, Fig. 10 shows that only the SFC is able to recover the stator flux after the 
load step, which is expected as the PFC was, per definition, not intended to achieve this objective. The SFC is even able to mitigate the overshoot in the stator flux by keeping the field current transiently low during the load transition. On the contrary, the PFC gets a high stator flux overshoot but also over-magnetization after the transition. This fact emphasizes the ability of the SFC to prevent the machine from becoming over-saturated after ramping up the pump load. The SFC is the only approach that can keep unity stator flux in the CFSM, satisfying the optimal flux regulation, independent of loading. This is further highlighted in Table VI, where a high overmagnetization is indicated for the PFC $(\geq 30 \%)$ after the load step. This is due to the fact that a higher loading level in the stator armature creates an additional flux linkage that the ES does not compensate against under PFC, as $i_{f d}$ is controlled to be constant.

In addition to the above, the SFC indicates better torqueper-ampere performance than the PFC method, as seen in Fig. 11. This is due to the fact that only the torque producing $\mathrm{q}$ axis current of the converter is used, while the d-axis current is regulated to zero. For the PFC, the d-axis current is used to improve the overall power factor of the converter, seen in Figure 9, meaning that the stator (and converter) current will be higher.

\section{Further Discussion}

The benefit of utilizing SFC is that the machine is operated without over-magnetization, which is beneficial for the operation of the electrical machine. While the $\cos (\varphi)=1$ control method maintains a unity power factor, thus minimizing reactive converter power, the decrease in power factor is rather small for the SFC method while keeping unitary stator flux. On the contrary, the main benefit of the PFC is the optimal converter operation. However, it does not yield any better gains over the SFC method because the current drawn by the machine from the converter was, in fact, found to be higher. The acceleration of the machine is comparable for all control methods and will be less important because the main function of a VSHP is its ability to vary its load optimally. It is worth mentioning that a fast frequency response measure was considered out of the scope of this study.

\section{CONClusion}

This paper presents a method to optimally control converterfed synchronous machines (CFSMs) by using the field current to maintain a unitary stator flux magnitude (i.e., $1.0 \mathrm{pu}$ ). The proposed stator flux control (SFC) method achieves a better torque-per-ampere performance than a unitary power factor control (PFC) method at the converter-side. The PFC relied on using the $\mathrm{d}$-axis current component of the converter to operate at unity power factor. While the $\cos (\varphi)=1$ control method minimizes reactive converter power, it inevitably draws a higher current, potentially nullifying the gains of a higher power factor than the SFC approach. In addition, the machine losses with PFC control will be higher due to the over-magnetized operation of the machine. The SFC shows comparable acceleration with the PFC control method.
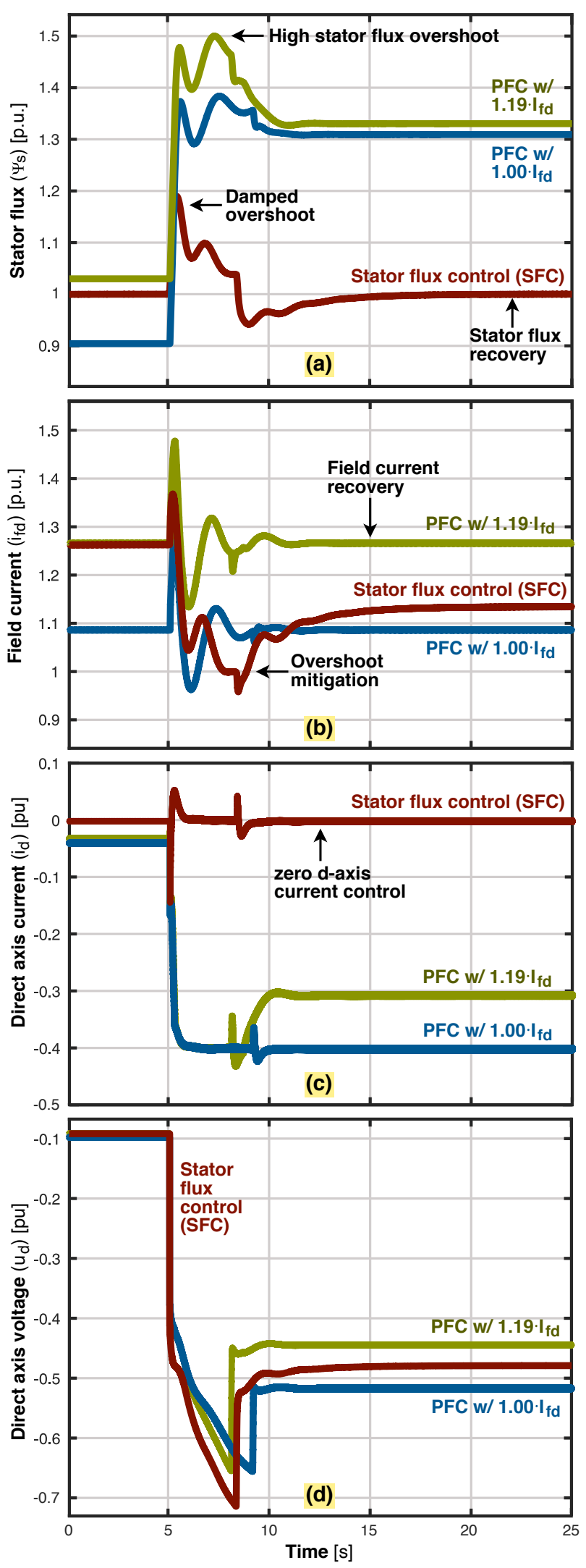

Fig. 10. Assessment of the different control strategies for same case as Fig. 8. a): Stator flux $\left(\Psi_{S}\right)$. b): Field current $\left(i_{d f}\right)$. c): Direct axis stator current $\left(i_{d}\right)$. d): Direct axis stator voltage $\left(u_{d}\right)$. 


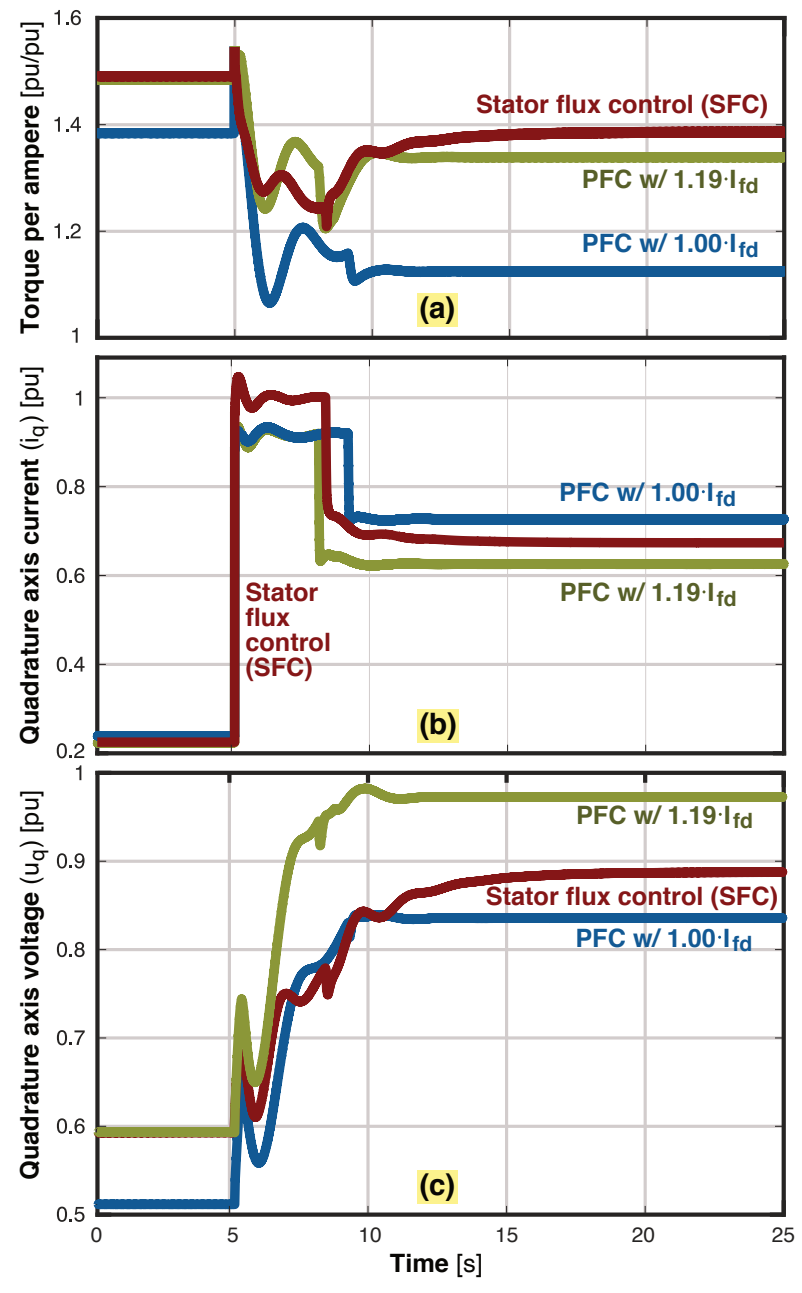

Fig. 11. Assessment of the different control strategies for same case as Fig. 8. a): Torque per ampere. b): Quadrature axis stator current $\left(i_{q}\right)$. c): Quadrature axis stator voltage $\left(u_{q}\right)$.

Future research items could involve examining and comparing machine losses due to magnetization against power losses in the converter. This could provide further evidence to support the SFC method as more beneficial than operating the machine with a unity power factor. Additionally, the tuning of the controller parameters could be further studied, especially the speed of response of the field current controller of the excitation system (ES). Finally, some sort of hybrid control strategy could be examined, particularly for low-speed operations where magnetization losses may be less important than power losses in the converter.

\section{REFERENCES}

[1] J. Markard, "The next phase of the energy transition and its implications for research and policy," Nature Energy, vol. 3, no. 8, pp. 628-633, 2018.

[2] L. Kitzing, M. K. Kofoed Jensen, T. Telsnig, and E. Lantz, "Multifaceted drivers for onshore wind energy repowering and their implications for energy transition," Nature Energy, pp. 1-10, 2020.

[3] W. Yang, P. Norrlund, L. Saarinen, A. Witt, B. Smith, J. Yang, and U. Lundin, "Burden on hydropower units for short-term balancing of renewable power systems," Nature Communications, vol. 9, no. 1, pp. 1-12, 2018.

[4] M. Valavi and A. Nysveen, "Variable-speed operation of hydropower plants: A look at the past, present, and future," IEEE Ind. Appl. Mag., vol. 24, no. 5, pp. 18-27, 2018.
[5] T. Tellefsen, J. van Putten, and O. Gjerde, "Norwegian hydropower: Connecting to continental europe," IEEE Power and Energy Mag., vol. 18 , no. 5, pp. 27-35, 2020.

[6] T. I. Reigstad and K. Uhlen, "Variable speed hydropower for provision of fast frequency reserves in the nordic grid," IEEE Trans. Power Syst., pp. 1-1, 2021.

[7] Z. Dong, J. Tan, E. Muljadi, R. M. Nelms, A. St-Hilaire, M. Pevarnik, and M. D. Jacobson, "Developing of quaternary pumped storage hydropower for dynamic studies," IEEE Trans. Sustain. Energy, vol. 11, no. 4, pp. 2870-2878, 2020.

[8] B. Li, Z. Duan, X. Wang, and J. Wu, "Loss-of-excitation analysis and protection for pumped-storage machines during starting," IET Renew. Power Gen., vol. 10, no. 1, pp. 71-78, 2016.

[9] A. Joseph, K. Desingu, R. R. Semwal, T. R. Chelliah, and D. Khare, "Dynamic performance of pumping mode of $250 \mathrm{MW}$ variable speed hydro-generating unit subjected to power and control circuit faults," IEEE Trans. Energy Convers., vol. 33, no. 1, pp. 430-441, 2018.

[10] A. Joseph, S. Kim, S. Sing Lee, A. Dominic, and K. Lee, "Boost multi-level npc-fed vs large rated asynchronous pumped storage hydrogenerating unit," IET Electr. Power Appl., vol. 13, no. 10, pp. 1488-1496, 2019.

[11] A. Joseph, R. Selvaraj, T. R. Chelliah, and S. V. A. Sarma, "Starting and braking of a large variable speed hydrogenerating unit subjected to converter and sensor faults," IEEE Trans. Ind. Appl., vol. 54, no. 4, pp. 3372-3382, 2018

[12] A. Joseph, T. R. Chelliah, R. Selvaraj, and K. Lee, "Fault diagnosis and fault-tolerant control of megawatt power electronic converter-fed largerated asynchronous hydrogenerator," IEEE J. Emerg. Sel. Topics Power Electron., vol. 7, no. 4, pp. 2403-2416, 2019.

[13] K. Desingu, R. Selvaraj, and T. R. Chelliah, "Control of reactive power for stabilized junction temperature in power electronic devices serving to a 250-mw asynchronous hydrogenerating unit," IEEE Trans. Ind. Appl., vol. 55, no. 6, pp. 7854-7867, 2019.

[14] Y. Pannatier, B. Kawkabani, C. Nicolet, J. Simond, A. Schwery, and P. Allenbach, "Investigation of control strategies for variable-speed pump-turbine units by using a simplified model of the converters," IEEE Trans. Ind. Electron., vol. 57, no. 9, pp. 3039-3049, 2010.

[15] I. Sami, N. Ullah, S. M. Muyeen, K. Techato, M. S. Chowdhury, and J. S. Ro, "Control methods for standalone and grid connected micro-hydro power plants with synthetic inertia frequency support: A comprehensive review," IEEE Access, vol. 8, pp. 176313-176329, 2020.

[16] A. Joseph and T. R. Chelliah, "A review of power electronic converters for variable speed pumped storage plants: Configurations, operational challenges, and future scopes," IEEE J. Emerg. Select. Topics Power Electron., vol. 6, no. 1, pp. 103-119, 2018.

[17] J. Koutnik, "Frades ii-variable speed pumped storage project and its benefit to the electrical grid," in Proc. Int. Conf. Renew. Energy, 2012, pp. 1-7.

[18] R. R. Semwal, R. Selvaraj, K. Desingu, T. R. Chelliah, and A. Joseph, "Two-stage protection circuit for a multichanneled power electronic converter fed large asynchronous hydrogenerating unit," IEEE Trans. Ind. Appl., vol. 55, no. 6, pp. 5947-5959, 2019.

[19] R. Selvaraj, K. Desingu, T. R. Chelliah, D. Khare, and C. Bharatiraja, "Fault tolerant operation of parallel-connected 3L-neutral-point clamped back-to-back converters serving to large hydro-generating units," IEEE Trans. Ind. Appl., vol. 54, no. 5, pp. 5429-5443, 2018.

[20] K. Desingu, R. Selvaraj, T. R. Chelliah, and D. Khare, "Effective utilization of parallel-connected megawatt three-level back-to-back power converters in variable speed pumped storage units," IEEE Trans. Ind. Appl., vol. 55, no. 6, pp. 6414-6426, 2019.

[21] M. Basić, A. Schwery, and D. Dujić, "Highly flexible indirect modular multilevel converter for high power pumped hydro storage plants," in Proc. 46th Ann. Conf. IEEE Ind. Electron. Soc., 2020, pp. 5290-5295.

[22] A. Joseph, T. R. Chelliah, and K. Lee, "Multi-channel vsi fed large variable speed asynchronous hydro-condenser: fault analysis, fault diagnosis and fault tolerant control," IET Renew. Power Gen., vol. 13, no. 3, pp. 438-450, 2019.

[23] R. Kumari, K. Desingu, T. R. Chelliah, and S. V. A. Sharma, "Development trends and future prospects of hydro-turbine control systems," in Proc. IEEE Ind. Appl. Soc. Ann. Meet., 2019, pp. 1-10.

[24] L. Belhadji, S. Bacha, I. Munteanu, A. Rumeau, and D. Roye, "Adaptive MPPT applied to variable-speed microhydropower plant," IEEE Trans. Energy Convers., vol. 28, no. 1, pp. 34-43, 2013.

[25] L. Ji, Y. Shao, J. Sun, and L. Shi, "Research on self-starting strategy of variable speed pumped storage units based on model predictive control," J. Eng., vol. 2017, no. 13, pp. 984-989, 2017. 
[26] L. Ji, J. Sun, M. Zhou, and W. Tian, "AC excitation control strategy of variable speed pumped storage units based on active disturbance rejection control," J. Eng., vol. 2017, no. 13, pp. 1195-1199, 2017.

[27] T. I. Reigstad and K. Uhlen, "Variable speed hydropower conversion and control," IEEE Trans. Energy Convers., vol. 35, no. 1, pp. 386-393, 2020.

[28] L. Wang, Q. Han, D. Chen, C. Wu, and X. Wang, "Non-linear modelling and stability analysis of the ptgs at pump mode," IET Renew. Power Gen., vol. 11, no. 6, pp. 827-836, 2017.

[29] R. Kumari, K. K. Prabhakaran, K. Desingu, T. R. Chelliah, and S. V. A. Sarma, "Improved hydroturbine control and future prospects of variable speed hydropower plant," IEEE Trans. Ind. Appl., vol. 57, no. 1, pp. 941-952, 2021.

[30] "Ieee draft guide for synchronous generator modeling practices and parameter verification with applications in power system stability analyses," IEEE P1110/D06, December 2018, pp. 1-91, 2019.

[31] A. S. AG, "Case note: 100 mva power converter for variable speed pumped hydropower," 2014.

[32] "Ieee recommended practice for excitation system models for power system stability studies," IEEE Std 421.5-2016 (Revision of IEEE Std 421.5-2005), pp. 1-207, 2016.

[33] V. Vittal, J. D. McCalley, P. M. Anderson, and A. Fouad, Power system control and stability. John Wiley \& Sons, 2019.

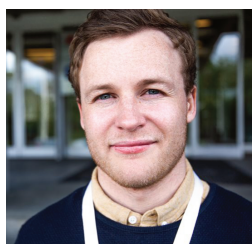

Jørgen Hagset Stavnesli received the MSc. degree in electrical power engineering from Norwegian Univerisity of science and technology in 2020. He is currently employed at ABB Marine and Ports, primarily working on system studies related to ABB's Onboard DC-Grid ${ }^{\mathrm{TM}}$ for marine vessels. He has previously been co-author of Performance Analysis of Oustaloup Approximation for the Design of Fractional-Order Analogue Circuits during a stay at the Technical University of Brno (VUT).

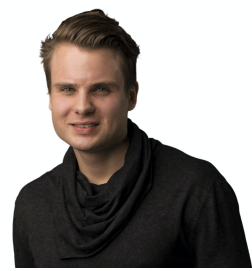

Jonas Kristiansen Nøland (S'14-M'17) was born in Drammen, Norway, in 1988. He received the M.Sc. degree in electric power engineering from the Chalmers University of Technology, Gothenburg, Sweden, in 2013, and the Ph.D. degree in engineering physics from Uppsala University, Uppsala, Sweden, in 2017. Since 2018, he has been an Associate Professor with the Department of Electric Power Engineering, Norwegian University of Science and Technology. His current research interests include excitation systems, hydrogenerators, large AC machines, and enhancing their utilization. Dr. Nøland serves as an Editor for the IEEE TRANSACTIONS ON ENERGY CONVERSION and as an Associate Editor for the IEEE TRANSACTIONS ON INDUSTRIAL ELECTRONICS. 